\title{
Premature Closure
}

National Cancer Institute

\section{Source}

National Cancer Institute. Premature Closure. NCI Thesaurus. Code C124571.

Fusion, stoppage, or loss of patency occurring before the usual or proper time. 